\title{
Parathyroid carcinoma and hungry bone syndrome
}

\author{
Carcinoma de paratiroide e fome óssea
}

Monique Nakayama Ohe', Rodrigo Oliveira Santos², Flavio Hojaij ${ }^{2}$, Murilo Catafesta Neves², Ilda Sizue Kunii', Denise Orlandi', Luisa Valle', Carla Martins' ${ }^{1}$ Carolina Janovsky', Rimarcs Ferreira ${ }^{3}$, Roseane Delcelo3, Ana Maria Domingos ${ }^{3}$, Marcio Abrahão², Onivaldo Cervantes², Marise Lazaretti-Castro', Jose Gilberto Henriques Vieira'

\begin{abstract}
'Division of Endocrinology and Metabolism, Escola Paulista de Medicina, Universidade Federal de São Paulo (Unifesp/ EPM), Sao Paulo, SP, Brazil

${ }^{2}$ Division of Head and Neck Surgery, Unifesp/EPM, Sao Paulo, SP, Brazil

${ }^{3}$ Department of Pathology, Unifesp/ EPM, Sao Paulo, SP, Brazil
\end{abstract}

Correspondence to:

Monique Nakayama Ohe Av. Cons. Rodrigues Alves, 804, ap. 51

04014-002 - Sao Paulo, SP, Brazil moniqueohe@uol.com.br

Received on Mar/19/2012 Accepted on Sept/8/2012

\section{SUMMARY}

We hereby report two patients with parathyroid carcinoma presenting extremely high calcium and PTH levels, severe bone disease, and palpable neck mass at diagnosis. They both underwent parathyroidectomy, and one of them evolved to lung metastasis. Important hypocalcemia was observed after surgery in both: after parathyroidectomy in one patient, and only after surgical removal of the metastasis in the other. Both required intravenous calcium replacement, thus revealing hungry bone syndrome (HBS). HBS usually reflects rapid mineralization after correction of hyperparathyroidism. The more severe the bone disease before surgery, the more prone the patient is to HBS after surgery. Despite being an unfavorable outcome, HBS state suggests that surgical removal of hypersecretory parathyroid tissue was accomplished. In this study, HBS was observed in both patients, who presented severe bone disease prior to surgery. HBS would be expected post-operatively in successful parathyroid carcinoma removal. Arq Bras Endocrinol Metab. 2013;57(1):79-86

\section{SUMÁRIO}

O presente artigo descreve o relato de dois pacientes com carcinoma de paratiroide que apresentavam valores intensamente elevados de cálcio sérico e de PTH, associado a doença óssea e presença de nódulo cervical palpável ao diagnóstico. Ambos foram submetidos à paratiroidectomia, sendo que um evoluiu com metástases pulmonares. Hipocalcemia importante foi observada após a paratiroidectomia em um paciente e somente após remoção cirúrgica das metástases pulmonares em outro. Ambos necessitaram de reposição endovenosa de cálcio, revelando, assim, o estado de fome óssea (FO). A presença da FO usualmente reflete rápida mineralização óssea após correção do hiperparatiroidismo; assim, quanto mais severa a doença óssea previa à cirurgia, maior será a FO observada no pós-operatório desses pacientes. Embora inicialmente considerada um evento indesejável, a FO representa a bem-sucedida remoção cirúrgica do tecido paratiroideano hipersecretor. Fome óssea deve ser esperada no pós-operatório do tratamento cirúrgico bem-sucedido do carcinoma de paratiroide. Arq Bras Endocrinol Metab. 2013;57(1):79-86

\section{INTRODUCTION}

$\mathrm{P}$ arathyroid carcinoma is a rare endocrine malignancy that was first described in 1904 by De Quervain (1). Subsequent descriptions of functioning parathyroid carcinomas were reported in the 1930s (2). Since then, only a few hundred cases have been reported in the literature. Parathyroid carcinoma is an uncommon cause of parathyroid hormone-dependent hypercalcemia, accounting for $0.4-5.2 \%$ of all primary hyperparathyroidism patients, and for $0.2-0.5 \%$ of all malignant endocrine tumors. It occurs equally in men and women (3), in contrast to benign hyperparathyroidism, which is more frequent in women than in men $(\sim 3: 1)$. 
The cause of parathyroid carcinoma is yet to be established, and at present, there is no data pointing out causal relationships between parathyroid carcinoma and risk factors. Recently, it has been described that both familial and sporadic forms (4) of parathyroid carcinomas are associated with various mutations in the HRPT2 gene on chromosome lq25-1q32, suggesting that HRPT2 acts as a tumor suppressor gene (5).

Optimal treatment is related to early diagnosis with clinical and laboratory suspicion of parathyroid carcinoma prior to surgery, once parathyroidectomy with complete resection of the primary site, en bloc, including the surrounding tissue, is intended (6). The natural history of parathyroid carcinoma is described as slow, but progressive. Morbidity and mortality usually result from unremitting hypercalcemia and its complications, rather than mass effect of tumor growth (7). Metastasis is common, and the most frequent compromised sites are lungs $(40 \%)$, cervical lymph nodes $(30 \%)$, and liver $(10 \%)(8)$.

We have previously reported our experience with seven patients with parathyroid carcinoma $(6,9)$ and, in this study, we present two other cases, with emphasis on hungry bone disease (HBS).

Hungry bone syndrome is described after successful parathyroidectomy; it is related to rapid bone remineralization causing hypocalcemia and requiring calcium and vitamin D replacement $(10,11)$.

\section{CASE REPORTS}

\section{Case 1}

A 65-year-old female patient was seen at the emergency ward at Hospital São Paulo - a Federal University Hospital - in 2008, complaining of fever, dysuria, nausea, loss of appetite, and loss of weight, as well as general malaise. She was initially diagnosed with acute exacerbation of chronic renal failure related to recurrent nephrolithiasis. At clinical examination, a palpable neck mass was observed. Laboratory tests revealed important hypercalcemia, with ionized calcium (iCa) of $1.9 \mathrm{mmol} / \mathrm{L}$ (reference values: $1.20-1.40 \mathrm{mmol} / \mathrm{L}$ ) and intact parathyroid hormone levels (iPTH) of $2,800 \mathrm{pg} / \mathrm{mL}$ (reference values $10-65 \mathrm{pg} / \mathrm{mL}$ ), in addition to evidence of renal failure, with serum creatinine values of $3.4 \mathrm{mg} / \mathrm{dL}$, creatinine clearance of $16.7 \mathrm{~mL} / \mathrm{min}$ (Cockcroft-Gault), and normo- chromic normocytic anemia. Besides, in renal ultrasound examination, renal cystic lesion was observed.

The patient was diagnosed with primary hyperparathyroidism and, thus, referred to surgery. In face of palpable neck mass at physical examination and markedly high levels of calcium and iPTH, she underwent en bloc resection of the lower right parathyroid, with ipsilateral thyroidectomy and isthmusectomy, followed by excision of paratracheal and central neck nodes, considering a possible diagnosis of parathyroid carcinoma. Intraoperative PTH (IO-PTH) was performed (Elecsys 1010 System, Roche, Mannheim, Germany) revealing $2,480 \mathrm{pg} / \mathrm{mL}$ at the induction of anesthesia, which dropped to $394 \mathrm{pg} / \mathrm{mL} 10$ minutes after the removal of the parathyroid gland $(84.1 \%$ decrease). Pathological examination showed a parathyroid carcinoma (sized $4.0 \times 3.3 \mathrm{~cm}$ ) with vascular invasion and tumor extension to adjacent thyroid. Just after surgery, the patient presented important decrease in phosphorus and calcium levels.

In the outcome, high levels of $\mathrm{iCa}$ and $\mathrm{iPTH}$ were observed $(\mathrm{iPTH}=287 \mathrm{pg} / \mathrm{mL}$; iCa $=1.55$ $\mathrm{mmol} / \mathrm{L}$ ) two months after surgery, which evolved to markedly abnormal laboratory findings with total serum calcium $(\mathrm{tCa})$ of $13.8 \mathrm{mg} / \mathrm{dL}$ (reference value $=8.5-10.5)$, iPTH of $2,127 \mathrm{pg} / \mathrm{mL}$, and iCa of $1.98 \mathrm{mmol} / \mathrm{L}$ one year after the surgical procedure. At this time, a $99 \mathrm{mTc}$ scintigraphy revealed hyperconcentration in the inferior left parathyroid.

The patient underwent surgical re-exploration with removal of the left superior and inferior parathyroids along with left lobe thyroidectomy and neck nodal dissection. Intraoperative PTH failed to drop: IO-PTH at the induction of anesthesia was $1,450 \mathrm{pg} / \mathrm{mL}$, and dropped to $986 \mathrm{pg} / \mathrm{mL}$; the patient remained hypercalcemic in the outcome $(\mathrm{iCa}=1.67 \mathrm{mmol} / \mathrm{L})$. In a search for distant metastases, the patient underwent pulmonary computerized tomography, and multiple pulmonary nodules were found (Figure 1). In July 2011, two years after the first surgical procedure, the patient underwent surgical resection of lung metastases. Six nodules were removed. Histological analysis revealed a metastatic carcinoma in pulmonary nodule, showing cells with round and hyperchromatic nuclei (Figure 2).

After surgery, we observed an important decrease in calcium and phosphorus $(\mathrm{P})$ levels since the second post-operative day that reached iCa of $0.91 \mathrm{mmol} / \mathrm{L}$ (reference values: $1.20-1.40 \mathrm{mmol} / \mathrm{L}$ ) and phosphorus 
of $1.9 \mathrm{mg} / \mathrm{dL}$ (reference values: $2.5-5.0 \mathrm{mg} / \mathrm{dL}$ ). We prescribed intravenous calcium and oral calcium carbonate $500 \mathrm{mg}$, two pills, four times a day, associated with oral calcitriol $0.25 \mu \mathrm{g}$ four times a day, plus cholecalciferol 3,000 UI a day in the first two post-operative days. We continued oral calcium, calcitriol and cholecalciferol replacement in lower doses for over two weeks, until the patient was discharged, which was done with her taking calcium carbonate $500 \mathrm{mg}$, three times a day, calcitriol $0.25 \mu \mathrm{g}$ two times a day, and cholecalciferol 2,000 UI a day. Another important finding was related to bone mineral density recovery 6 months after lung metastasis removal (Table 1 ).
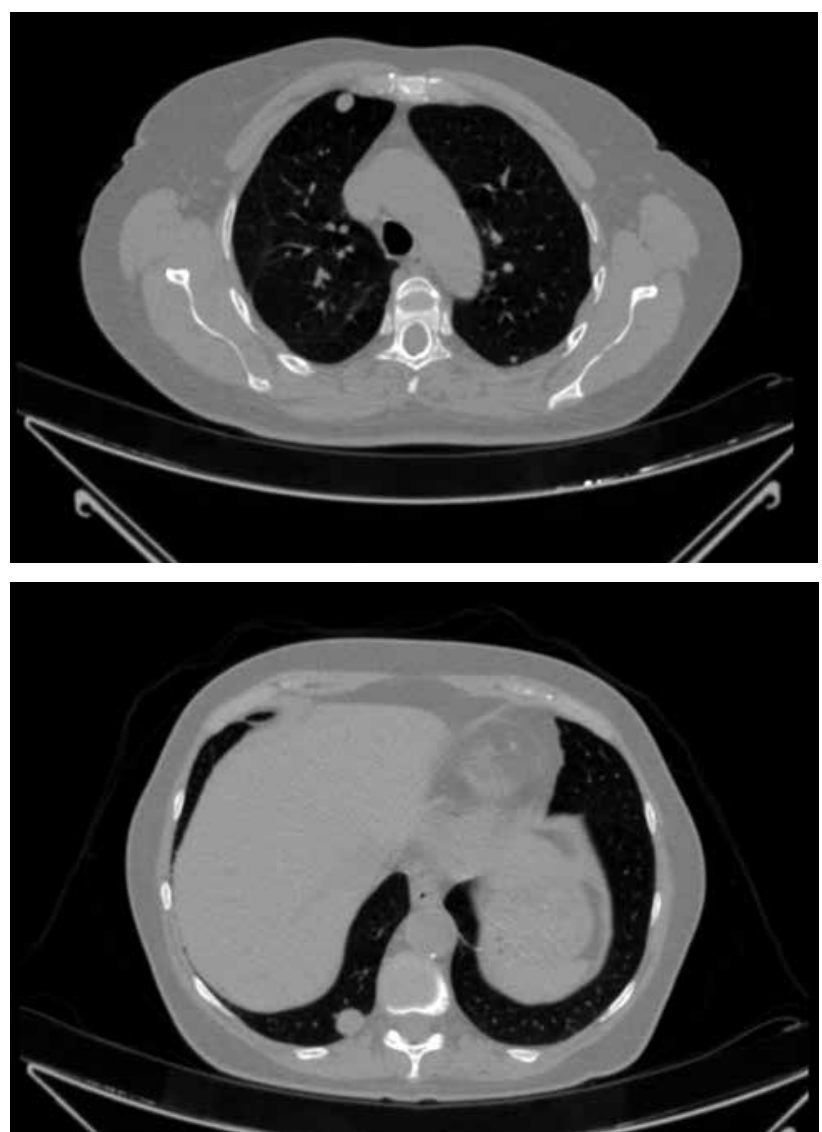

Figure 1. Pulmonary computed tomography: $1.0-\mathrm{cm}$ nodule in the upper right anterior pulmonary lobe, and $1.7-\mathrm{cm}$ nodule in the lower right pulmonary lobe.

Table 1. Bone mineral density recovery after removal of lung metastasis

\begin{tabular}{llrlr}
\hline & \multicolumn{2}{c}{$\mathbf{1 2 / 2 0 0 8}$} & \multicolumn{2}{c}{$\mathbf{1 2 / 2 0 1 1}$} \\
\hline & BMD $\left(\mathrm{g} / \mathrm{cm}^{2}\right)$ & T-score & BMD $\left(\mathrm{g} / \mathrm{cm}^{2}\right)$ & T-score \\
L1-L4 & 0.814 & -2.1 & 1.170 & -0.1 \\
Neck & 0.779 & -0.6 & 1.060 & +0.2 \\
Total femur & 0.907 & -0.3 & 1.144 & +1.1 \\
\hline
\end{tabular}

BMD: bone mineral density; L1-L4: lumbar spine; neck: femoral neck.

\section{Case 2}

A 42-year-old female patient was referred to the emergency ward at Hospital São Paulo in July 2011, complaining about ocular disturbances in the previous five months with ptosis, palpebral swelling, and diplopia. She also complained about nausea and vomiting, polyuria and polydipsia, constipation and painful gait involving the right hip and lumbar spine. She had already reported several episodes of nephrolithiasis treated by lithotripsy. At physical examination, she was underweight, anemic, and dehydrated. A palpable neck mass of $3.0 \mathrm{~cm}$ was observed. Laboratory tests revealed important hypercalcemia with iCa of $2.41 \mathrm{mmol} / \mathrm{L}$ (reference values: $1.20-1.40 \mathrm{mmol} / \mathrm{L}$ ), total calcium serum $(\mathrm{tCa})$ of $16.6 \mathrm{mg} / \mathrm{dL}$ (reference values of 8.5-10.5 mg/dL), iPTH of $1,394 \mathrm{pg} / \mathrm{mL}$ (reference values $10-65 \mathrm{pg} / \mathrm{mL}$ ), normochromic normocytic anemia, and normal kidney function.
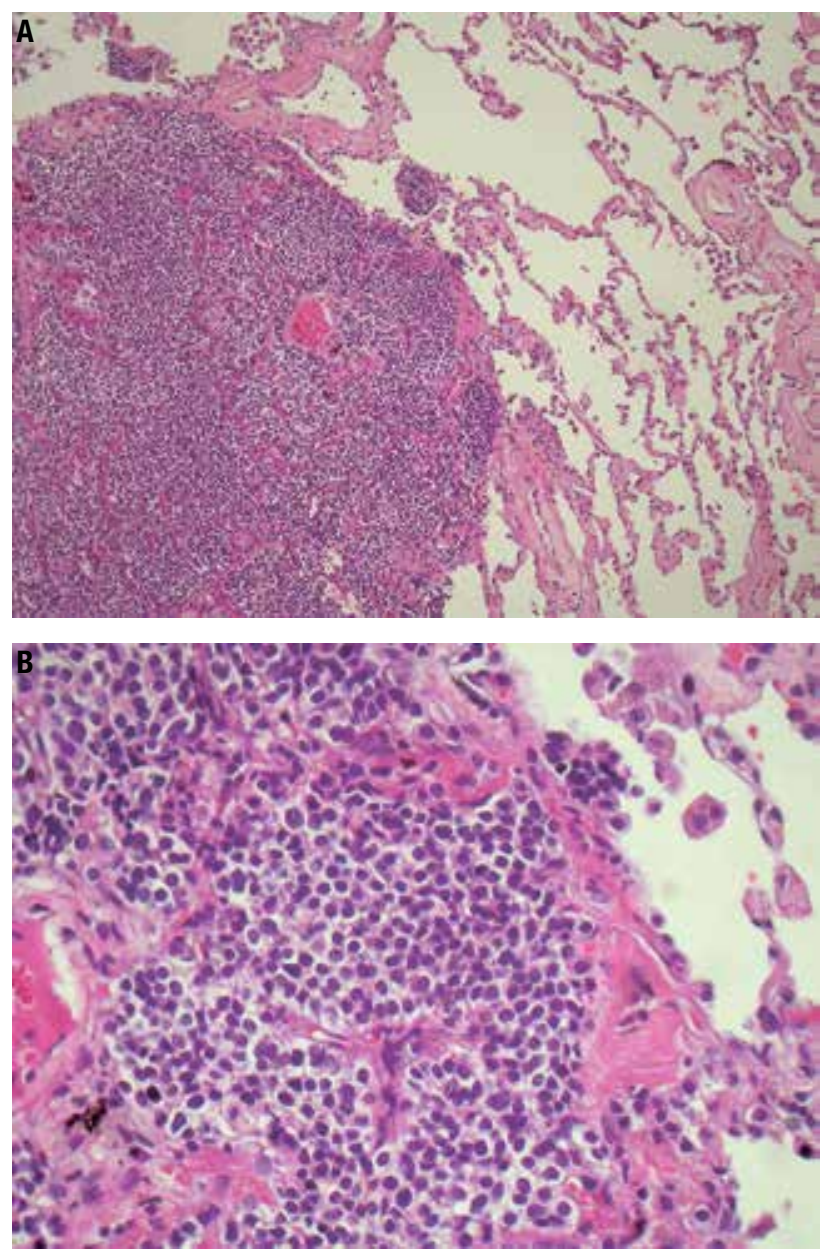

Figure 2. (A) Metastatic carcinoma nodule in lung (HE, 100X). (B) Cells with round and hyperchromatic nuclei (HE, 200X). 
A computerized tomography revealed a supraorbital expansive lesion (Figure 3 ), and a $6.0 \mathrm{~cm}$ expansive and heterogeneous lesion in iliac bone (Figure 4), both suggestive of brown tumor; $99 \mathrm{mTc}$ scintigraphy revealed hyperconcentration around the lower left thyroid lobe that persisted in the late images, which was suggestive of parathyroid gland.

The patient was then referred to surgery considering the hypothesis of parathyroid carcinoma in face of palpable neck mass at physical examination and marked high levels of calcium and iPTH. Thus, she underwent en bloc resection of the lower left parathyroid, with total thyroidectomy, followed by excision of bilateral paratracheal neck nodes ( $\mathrm{Fi}$ gure 5 ). The intraoperative aspect revealed an enlarged parathyroid of $4.0 \times 3.3 \mathrm{~cm}$, with heterogeneous appearance and attached to surrounding thyroid. The three remaining parathyroids presented normal appearance. Intraoperative PTH was performed (Elecsys 1010 System, Roche, Mannheim, Germany) and revealed $619 \mathrm{pg} / \mathrm{mL}$ at the induction of anesthesia, which dropped to $93 \mathrm{pg} / \mathrm{mL} 10$ minutes after the removal of the parathyroid gland ( $85 \%$ percent decrease).

Histological examination revealed a parathyroid carcinoma of $3.8 \mathrm{~cm}$ with focal capsular invasion, moderate to marked nuclear atypia and tumoral macronucleoli (Figure 6). Absence of lymph node metastasis and papillary carcinoma with follicular variant of $0.4 \mathrm{~cm}$ was observed in the right thyroid lobe. In the first post-operative day, in face of im-

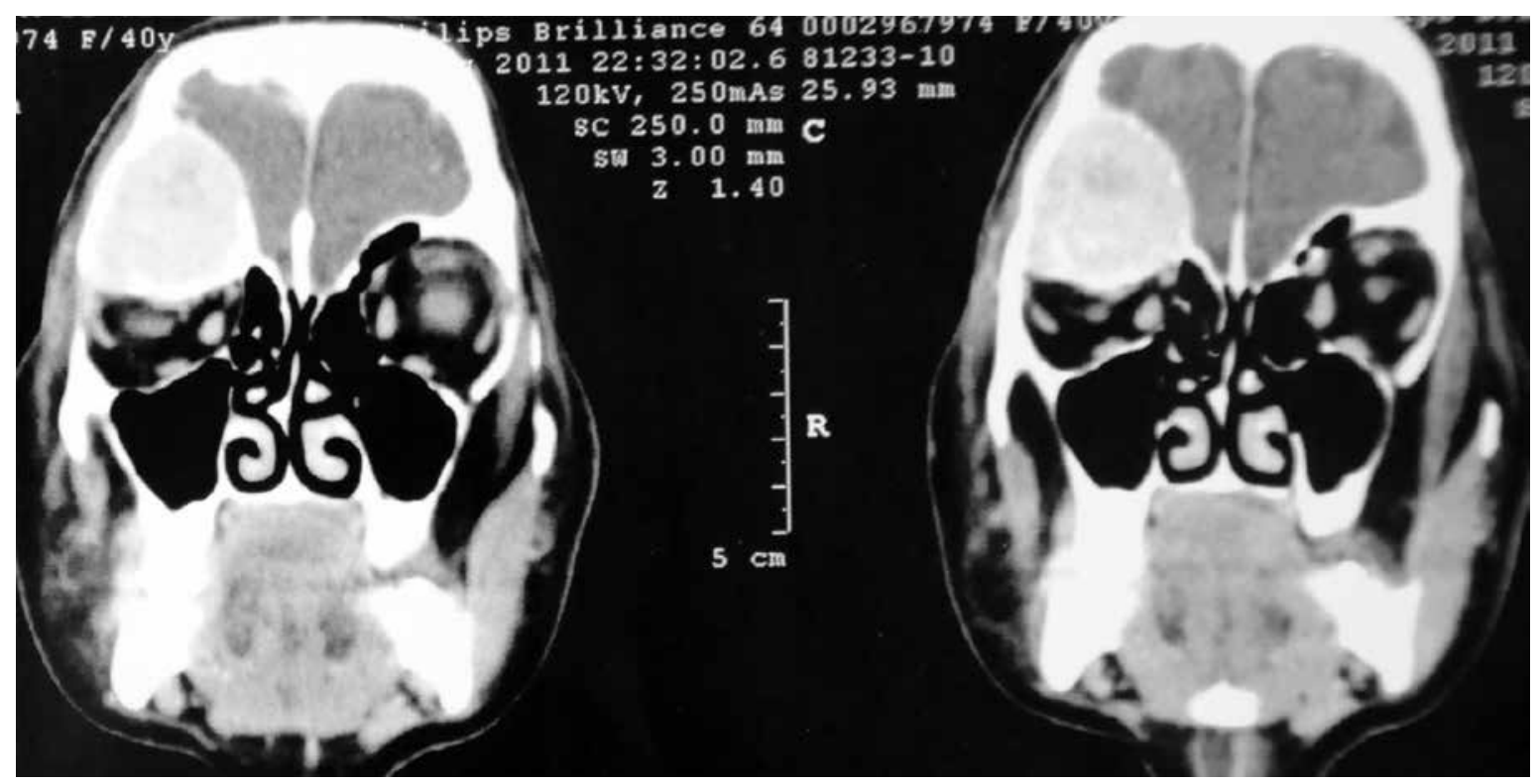

Figure 3. Computed tomography: supraorbital expansive lesion suggestive of brown tumor.

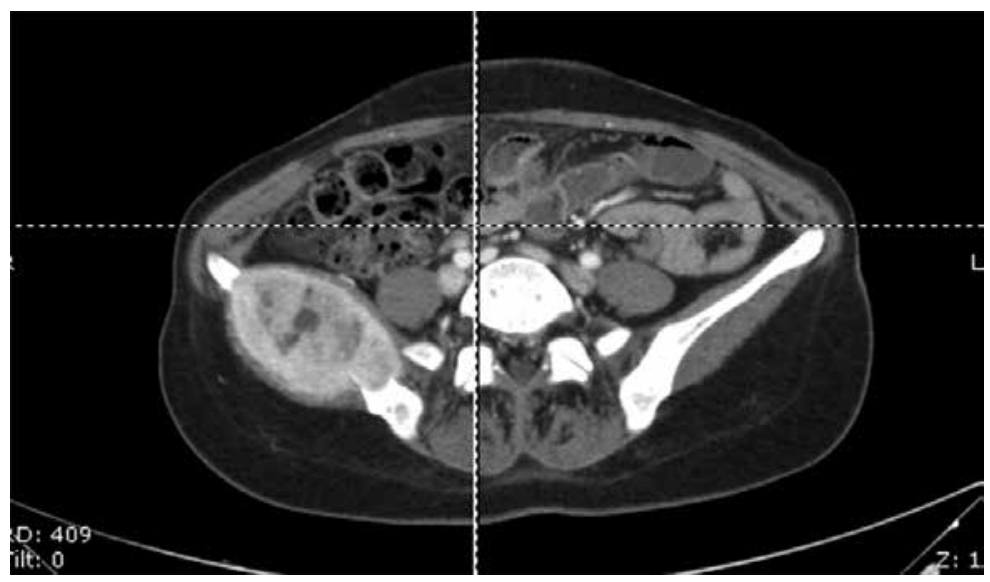

Figure 4. Computed tomography: expansive and heterogeneous lesion in the iliac bone, suggestive of brown tumor. 


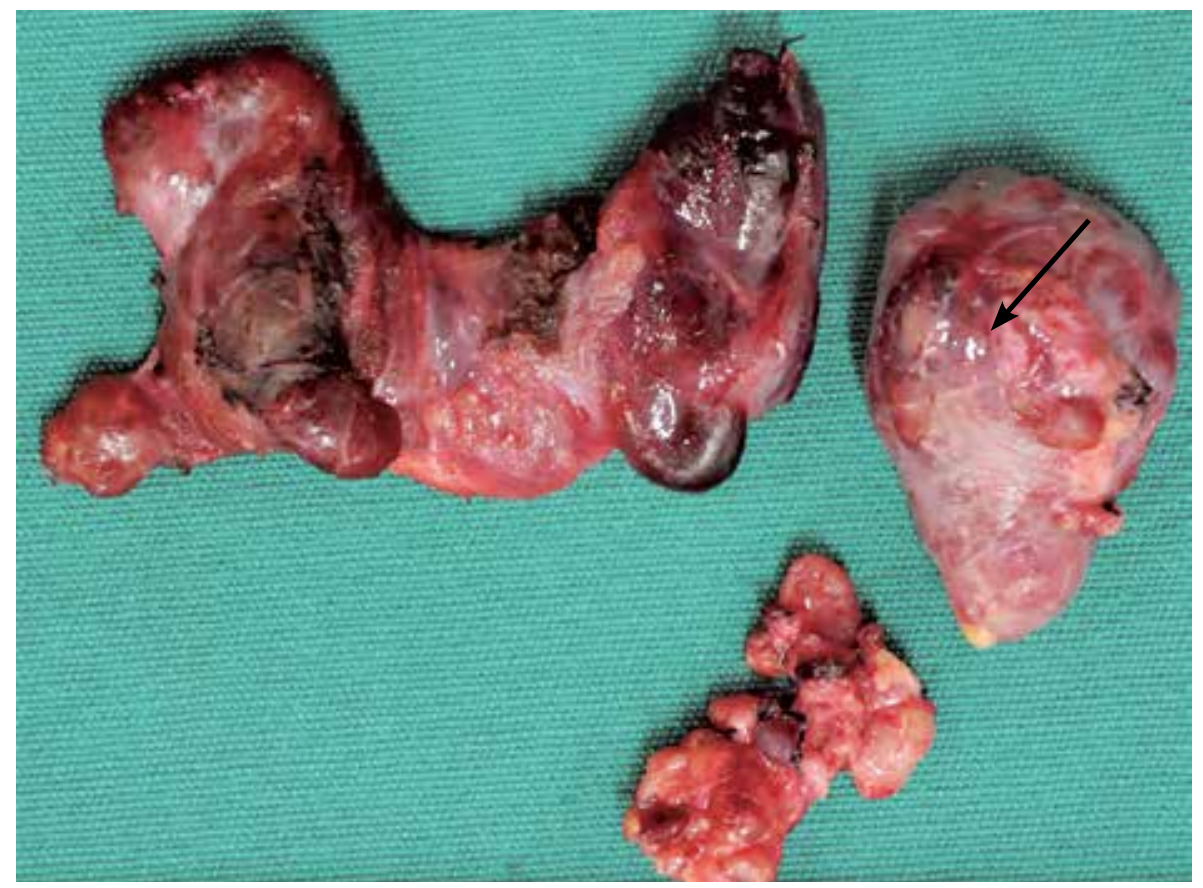

Figure 5. En bloc resection: nodular thyroid, parathyroid (arrow), and lymph-nodes.
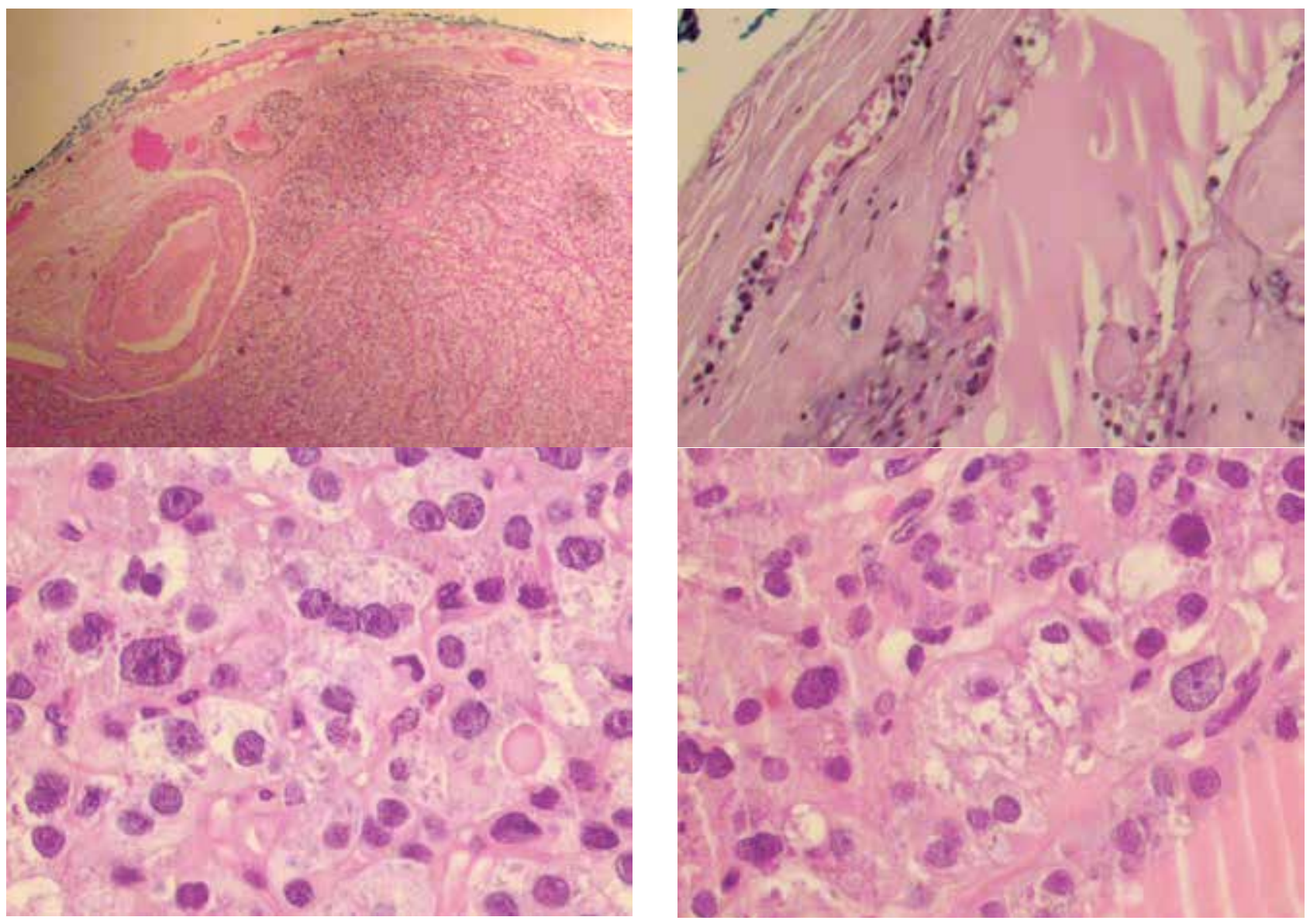

Figure 6. Parathyroid carcinoma with focal capsular invasion, moderate to accentuated nuclear atypia, and presence of macronucleoli (HE). 
portant bone lesions and high risk of hypocalcaemia, intravenous calcium replacement was prescribed. In the second post-operative day, after intravenous calcium replacement and taking calcium carbonate 500 $\mathrm{mg}$, two pills four times a day, associated with oral calcitriol $0.25 \mu \mathrm{g}$ three times a day, plus cholecalciferol 3,000 UI a day, serum calcium was at lower normal limit of $8.5 \mathrm{mg} / \mathrm{dL}$. She was discharged taking calcium carbonate $500 \mathrm{mg}$, two pills three times a day, calcitriol $0.25 \mu \mathrm{g}$ three times a day, plus cholecalciferol 3,000 UI a day. In the last six months of follow-up, she remained normocalcemic under oral calcium and cholecalciferol replacement.

\section{DISCUSSION}

Parathyroid carcinoma is the least common endocrine malignancy, with prevalence of $0.005 \%$ of all cancers (3). It is a rare malignant disease, likely to recur, and difficult to control. Several reports have highlighted the importance of en bloc resection, including thyroid lobectomy with the isthmus, paratracheal, and central neck nodal dissection $(8,12,13)$. This procedure, when performed as the initial therapeutic approach, provides patients with the best chance of cure. Recurrence after surgical excision of parathyroid carcinoma is common, with rates ranging from $33 \%$ to $78 \%$ (13). The reported time from surgery to the first recurrence (diseasefree interval) varies greatly, from 1 month to 20 years, with the most commonly reported mean between 2 and 5 years (14). Metastasis to lungs, mediastinum, and lymph nodes are described and difficult to control. When metastatic parathyroid tumors are found, surgical resection of metastatic tumors is the optimal treatment, once parathyroid carcinoma is refractory to radiation and cytotoxic reagents (8). Symptoms associated with metastatic lesions are typically due to hypercalcemia rather than tumor invasion (14). Studies reporting statistical estimates of disease-specific survival in patients with parathyroid carcinoma have yielded 5 -year survival rates ranging from $20 \%$ to $90 \%$, and 10 year survival rates between $42 \%$ and $86 \%$. Variations of the survival rates reported in these studies may reflect the differences in histopathology definitions, the proportions of unequivocal versus equivocal cases, and the initial therapeutic interventions used.

In a recent article (15), the authors reviewed the outcomes of parathyroid cancer patients treated at the same institution over a 43-year period (between 1966 and 2009), and evaluated the factors associated with recurrence and mortality. Specific factors that were independently associated with increased mortality included lymph node metastases, distant metastases, higher calcium level at recurrence, higher number of calciumlowering medications, and number of neck recurrences. Factors that were not associated with mortality included gender, race, age at diagnosis, calcium level at time of cancer diagnosis, tumor size, number of neck dissections, time of first recurrence, and decade in which treatment was initiated. Interestingly, the extent of operation (parathyroidectomy alone $v s$. parathyroidectomy with partial or total thyroidectomy) was not associated with mortality, either, nor was it associated with the number of recurrences or neck dissections necessary.

The authors usually resected en bloc only the soft tissue that appears to be involved with the cancer $(i . e$. the thyroid lobe, the esophagus, the trachea, the recurrent laryngeal nerve etc.) at the time of the initial operation, and resect any lymph nodes of abnormal appearence. However, having the initial operation done by an experienced parathyroid surgeon was associated with decreased mortality. The authors concluded that if there is high pre-operative suspicion of parathyroid cancer because of severe hypercalcemia or palpable parathyroid mass, one should consider referring the patient to a specialized tertiary center.

Parathyroid carcinoma is often misdiagnosed preoperatively as primary hyperparathyroidism due to parathyroid adenoma or hyperplasia. Clinical and laboratory findings may suggest carcinoma, but these findings are nonspecific. Even so, there is no external independent standard reference for the diagnosis of parathyroid carcinoma. Marked elevated serum calcium (often over 14 $\mathrm{mg} / \mathrm{dL}$ ), and intact parathyroid hormone levels (over five times the upper normal limit) should raise a clinical suspicion of this rare entity. A palpable neck mass has been reported in approximately half of the patients with parathyroid carcinoma, but in less than $1 \%$ of patients with primary hyperparathyroidism $(6,9,16)$. In this case study, we report two patients presenting marked high levels of serum calcium and intact $\mathrm{PTH}$, with severe clinical symptoms and presence of palpable neck mass at diagnosis, thus raising the suspicion of parathyroid carcinoma. Taking this hypothesis into account, both patients underwent en bloc parathyroid resection in accordance with the standard surgical procedure described for this rare condition. 
Regarding histopathology diagnosis, it is worth highlighting the current difficulties in pathological diagnosis concerning parathyroid carcinoma, once cellular pleomorphism and atypia are not reliable indicators of malignancy in endocrine tumors. Nevertheless, presence of trabecular growth pattern, capsular invasion, and vascular invasion are considered highly specific findings concerning parathyroid carcinoma (17). In this case study, patients presented capsular or vascular invasion in the parathyroid lesion.

Lung metastasis was observed in the post-operative outcome of one patient (case 1), two years after the first parathyroidectomy. That patient underwent surgical removal of the lung metastasis and revealed marked hypocalcemia, thus requiring intravenous calcium infusion - the hungry bone syndrome was then installed.

The hungry bone syndrome is described after parathyroidectomy, since correction of hyperparathyroidism is associated with rapid bone remineralization, causing severe and prolonged hypocalcemia that requires intensive intravenous calcium and oral vitamin D supplementation $(10,11)$. HBS is considered a complication of parathyroid surgery observed in 13-30\% of cases (18), and some studies advocate the use of bisphosphonates prior to surgery in order to prevent this post-operative outcome (19). The more severe the bone disease before surgery, the more prone the patient is to the hungry bone syndrome after the surgical procedure. Despite being an unfavorable outcome, the hungry bone syndrome state suggests that surgical removal of hypersecretive parathyroid tissue was accomplished. In this study, HBS was observed in both patients: in case 1 after lung metastasis removal, and in case 2 after surgical resection of the parathyroid lesion. Both patients presented severe bone disease prior to surgery. Therefore, it is worth highlighting that HBS would be expected post-operatively in successful parathyroid carcinoma removal.

Hungry bone syndrome treatment requires calcium and vitamin D replacement. Calcium carbonate is usually recommended and intravenous calcium replacement may be temporarily necessary in severe forms of HBS, as observed in both reported cases. Along with calcium, therapy with vitamin $\mathrm{D}$ is almost always required; $1,25(\mathrm{OH}) 2 \mathrm{D} 3$ (calcitriol), the active metabolite of vitamin $\mathrm{D}$, maintains serum calcium, in part, by improving the efficiency of intestinal calcium absorption. Calcitriol is administered over a wide dos- ing range -0.25 to $2 \mu \mathrm{g} / \mathrm{d}$ - and can increase serum calcium concentration substantially within 3 days (20). A single daily dose is typically administered in modest doses $(0.25$ to $0.75 \mu \mathrm{g} / \mathrm{d})$. When higher amounts are required, calcitriol is typically administered in divided doses. Vitamin D3 (cholecalciferol) is often used along with the active vitamin D metabolite (20). The longer half-life of cholecalciferol (2-3 weeks) helps to provide smoother control in view of the very short half-life of calcitriol, which is measured in hours.

In conclusion, parathyroid carcinoma is a rare and severe entity, with marked clinical and laboratory manifestations at diagnosis. The optimal treatment is related to early diagnosis with clinical and laboratorial suspicion for this entity prior to surgery, once complete resection of primary site is intended. Parathyroid carcinoma is a disease likely to recur and difficult to control. Hungry bone syndrome observed reflects the rapid mineralization after correction of hyperparathyroidism, and is related to bone disease severity prior to surgery. HBS may be expected as a post-operative outcome in successful parathyroid carcinoma.

Disclosure: no potential conflict of interest relevant to this article was reported.

\section{REFERENCES}

1. De Quervain F. Parastruma maligna aberrata [Malignant aberrant parathyroid] Deusche Zeitschr Chir. 1904;100:334-52.

2. Sainton $P$, Millot J. Malegne dún adenoma parathyroidiene eosinophile [Malignant eosinophilic parathyroid]. Au cours dune de Recklinghausen. Ann Anal Pathol. 1933;10:813.

3. Hundahl SA, Fleming ID, Fremgen AM, Menck HR. Two hundred eigth-six cases of parathyroid carcinoma treated in the US between 1985-1995: a National Cancer Data Base Report. The American College of Surgeons Commission on Cancer and the American Cancer Society. Cancer. 1999;86:538-44.

4. ShattuckTM, Valimaki S, ObaraT, Gaz RD, Clark OH, Shoback D, et al. Somatic and germ-line mutations of the HRPT2 gene in sporadic parathyroid carcinoma. N Engl J Med. 2003;349:1722-9.

5. Carpten JD, Robbins CM, Villablanca A, Forsberg I, Presciuttini $\mathrm{S}$, Bailey-Wilson J, et al. HRPT2 encoding parafibromin, is mutated in hyperparathyroidism-jaw tumor syndrome. Nat Genet. 2002;32:676-80.

6. Vieira JGH, Ohe MN, Hauache OM, Oliveira UM, Delana JM, Gonçalves $A$, et al. Carcinoma de paratiróide. Arq Bras Endocrinol Metab. 2005;49/5:811-5.

7. Obara T, Okamoto T, Ito $\mathrm{Y}$, Yamashita T, Kawano M, Nishi T, et al. Surgical and medical management of patients with pulmonary metastasis from parathyroid carcinoma. Surgery. 1993;114:1040-9.

8. Shane E. Clinical review 122: parathyroid carcinoma. J Clin Endocrinol Metab. 2001;86:485-93.

9. Morimitsu LK, Uyeno MNO, Goulart ML, Hauache OM, Vieira JGH, Alberti VN, et al. Carcinoma de paratiróide: características 
clínicas e anátomo-patológicas de cinco casos. Arq Bras Endocrinol Metab. 2001;45:148-56.

10. Headley CM. Hungry bone syndrome following parathyroidectomy. Anna J. 1998;25(3):283-9.

11. Rathi MS, Ajjan R, Orme SM. A case of parathyroid carcinoma with severe hungry bone syndrome and review of literature. Exp Clin Endocrinol Diabetes. 2008;116(8):487-90.

12. Fujimoto Y, Obata T, Ito Y, Kanazawa K, Aiyoshi Y, Nobori M. Surgical treatment of ten cases of parathyroid carcinoma: importance of an initial en block resection. World J Surg. 1984;8:392-400.

13. Kebebew E, Arici $\mathrm{C}$, Duh $\mathrm{Q}$, Clark $\mathrm{OH}$. Localization and reoperation results for persistent and recurrent parathyroid carcinoma. Arch Surg. 2001;136:878-85.

14. Silverberg SJ, Rubin MR, Faiman C, Peacock M, Shoback DM, Smallridge RC, et al. Cinacalcet hydrochloride reduces the serum calcium concentration in inoperable parathyroid carcinoma. J Clin Endocrinol Metab. 2007;92:3803-8.

15. Harari A, Waring A, Fernandez-Ravier G, Hwang J, Suh I, Mitmaker $E$, et al. Parathyroid carcinoma: a 43-year outcome and survival analysis. J Clin Endocrinol Metab. 2011;96:3679-86.
16. Cordeiro A, Montenegro F, Kulcsar M, Dellanegra LA, Tavares MR, Michaluart P Jr, et al. Parathyroid carcinoma. Am J Surg. 1998;175:52-5.

17. Obara T, Fujimoto $Y$, Hirayama $A$, Kanaji $Y$, Ito $Y$, Kodama T, et al. Flow cytometric DNA analysis of parathyroid tumors with special reference to its diagnostic and prognostic value in parathyroid carcinoma. Cancer. 1990;65(8):1789-93.

18. Ajmi S, Sfar R, Trimeche S, Ben Ali K, Nouira M. Scintigraphic findings in hungry bone syndrome following parathyroidectomy. Rev Esp Med Nucl. 2010;19(2):81-3.

19. França TC, Griz L, Pinho J, Diniz ET, Andrade LD, Lucena CS, et al. Bisphosphonates can reduce bone hunger after parathyroidectomy in patients with primary hyperparathyroidism and osteitis fibrosa cystica. Rev Bras Reumatol. 2011;51(2):131-7.

20. Bilezikian JP, Khan A, Potts Jr JT, Brandi ML, Clarke BL, Shoback $D$, et al. Hypoparathyroidism in the adult: epidemiology, diagnosis, pathophysiology, target-organ involvement, treatment, and challenges for future research. J Bone Miner Res. $2011 ; 26(10): 2317-37$. 